\title{
Mobility of Informal Sector Migrant Workers: History, Process, and Model of Decision to Settle in the Destination Area
}

\author{
Desak Putu Eka Nilakusmawati ${ }^{1,2}$ (Corresponding author) \\ ${ }^{1}$ Mathematics Department, Udayana University \\ Kampus Bukit Jimbaran, Badung, Bali, Indonesia \\ ${ }^{2}$ Center for Population Research and Human Resource Development, Udayana \\ University \\ Kampus Jl. P.B. Sudirman Denpasar, Bali, Indonesia \\ E-mail: nilakusmawati@unud.ac.id \\ I Gusti Ayu Made Srinadi \\ Mathematics Department, Udayana University \\ Kampus Bukit Jimbaran, Badung, Bali, Indonesia \\ E-mail: srinadi@unud.ac.id
}

Received: Sep. 23, $2020 \quad$ Accepted: Nov. 2, 2020 Online published: Nov. 18, 2020

doi:10.5296/ijhrs.v10i4.17953ＵRL: https://doi.org/10.5296/ijhrs.v10i4.17953

\begin{abstract}
This study determines the mobility of informal sector migrant workers from outside Bali in Denpasar City, Bali, Indonesia including the history of mobility before arriving in Denpasar City, the mobility process, and the decision model for settling in the destination area. The research was conducted in two locations in Denpasar City, namely West Denpasar District and South Denpasar District. The research data were collected by interview using a questionnaire and sampling was done by purposive sampling. History of mobility of migrant workers before arriving in Denpasar City, had lived in other places before their current place. The previous residence was another village in one sub-district and another sub-district in Denpasar City. The most reason for the decision to do mobility is dominated by the reason for getting a job. The reason for migrants to choose to work in Denpasar City is because the
\end{abstract}


salaries/wages are higher than in their home areas and it is easier to find job than in their home regions. Most of respondents waited for their first job $\leq 3$ weeks, with the source of assistance in getting the first job dominated by assistance from family/relatives. The source of assistance in finding a place to live for the first time, partly by their ownself, and the rest are accommodated by relatives/family. Significant factors influencing migrants' decision to plan to settle in the destination are the variables of Age, working hours per day, status of home ownership, source of assistance for first-time residence, and sub-district of the respondent's residence.

Keywords: mobility, migrant workers, mobility process, model of decision

\section{Introduction}

The rapid tourism sector and other sectors in Bali require a large workforce, and the workforce in Bali is inadequate so it needs to be supplied by workers outside Bali. Generally they come from the area closest to Bali, namely East Java and Lombok. The need for workers outside of Bali then becomes an opportunity that is used by migrants from outside Bali to meet their expectations in finding work in Bali. The arrival of migrant workers to Bali, aside from the above reasons, is also due to labor wages in Bali being far higher than in other regions, for example East Java.

The increasing number of migrants entering Bali Province has an impact on the high population density and labor problems. Generally they head to cities, especially Denpasar City so that the highest population density occurs in Denpasar City and Denpasar City has the highest number of migrant populations compared to districts/cities in Bali Province.

In addition, the impact of in-migration to the Province of Bali was on the high rate of population growth from the previous year period. The migrants who came consisted of several kinds of ethnicity, and this meant that the ethnic heterogeneity in Bali was even greater. The above conditions indicate the large role of migrants in increasing the rate of population growth in Bali Province.

Migrant workers mostly work as employees and workers in the tourism industry in the formal sector. Whereas in the informal sector, many migrant workers work in the types of jobs as street vendors, hawkers, individual service providers, and other types of work that are included in the informal sector classification. According to data from the Central Bureau of Statistics (BPS) of the Bali Province (2012), 1,065.05 thousand people (46.95\%) work in formal activities and 1,203.66 thousand people (53.05\%) work in informal activities, which indicates the large role of the informal sector in Bali.

The arrival of migrant workers in the city of Denpasar is in hopes of improving their socioeconomic conditions rather than in their home regions. The influx of migrants has both positive and negative impacts on the city of Denpasar and the area of origin. The positive impact is the filling of the need for labor in certain types of work that are starting to be abandoned by the native of Bali. Besides because workers from Bali tend to prefer to do jobs with higher wages, for example in the fields of carving, painting, construction of traditional Balinese buildings, and starting to leave the menial jobs. This menial work is generally done 
by migrant workers.

Besides that, the number of migrants coming to Bali has an impact on the high population density and the high rate of population growth in the city of Denpasar. In 1990 the population density of Bali Province was 493.1 people per $\mathrm{km}^{2}$ (BPS, 1993), in 2000 it increased to 554.5 people per $\mathrm{km}^{2}$ (BPS, 2000). This density figure is the highest population density in the provinces in Indonesia except on the island of Java, and this figure is more than 5 times the population density in Indonesia, which is 106 people. In 2010 the population density of Bali Province became 690 people per $\mathrm{km}^{2}$ (BPS of Bali Province, 2010).

Generally they head to cities, especially Denpasar City so that the highest population density occurs in Denpasar City. In 1995 the population density of Denpasar City was 2939 people $/ \mathrm{km}^{2}$ (Bappeda \& BPS, 1999), in 2000 it increased to 4213.8 people $/ \mathrm{km}^{2}$ (BPS, 2000), and in 2010 it became 6,170 people $/ \mathrm{km}^{2}$ (BPS of Bali Province, 2010).

The impact of the in-migration to the Province of Bali was on the high rate of population growth from the previous year period. The rate of population growth per year in the period 1980-1990 in Bali Province was 1.18\%. In the same period (1980-1990) Indonesia's population growth rate was $1.97 \%$ (Kasto \& Sembiring, 1996), in the period 1990-2000 the population growth rate of the Bali Province became 1.22\% and Denpasar City in the same year period has a population growth rate of $3.01 \%$ (BPS, 2000). Then according to the 2010 Population Census data, in the period 2000-2010 the population growth rate of the Province of Bali rose again to $2.15 \%$ (national figure: $1.49 \%$ ).

For Denpasar City where mobility was the highest among other districts, the most migrants were Javanese (22.61\%), followed by China (1.32\%), Sasak (0.88\%), and Madura (0.78\%), as well as other ethnic groups (BPS, 2000). The life-time migrant who entered the Province of Bali according to the 1971 Population Census of 23,000 people (1.0\% of the population), then in 2010 the number increased to nearly 407,000 people (10.46\%). Likewise, the recent migrant, according to the results of the 1990 Population Census the number of positive net recent migration in Bali Province reached 9,840 people, increased to 40,000 people (2010 Population Census), and according to the 2010 Population Census it increased again to more than 60,000 .

The arrival of workers from outside Bali, besides on their own initiative, headed to Bali with the aim of finding work in order to improve their standard of living than in the area of origin. Their arrival is also often because they are brought by building contractors who are also outsiders from Bali, the contractors often choose to bring their own workers from their home regions, because based on consideration of wages for workers outside Bali that are lower than workers from Bali, this will cause more and more non-permanent migrants. After the construction of the project is completed, often the migrant worker stays in the destination area, looking for work on his own initiative or with the help of relatives or friends who come from the same origin. This also led to the emergence of many migrant workers who ended up working in the informal sector.

Based on the above background, several research questions emerge, including: How is the 
general picture of the demographic and socio-economic characteristics of informal sector migrant workers from outside Bali? What is the history of mobility before arriving in Denpasar City? What factors influence the decision to do mobility? How is the departure to the destination? How was the adjustment process in the destination in getting the first job and residence? And what is the decision model for settling /not in the destination based on the demographic, socio-economic characteristics of migrants? What are the recommendations for sustainable policies that enable the structuring of migrant workers in the informal sector in Denpasar City?

Based on the research questions above, it is important to examine the characteristics of informal sector migrant workers from outside Bali in Denpasar, the history of mobility, the process of making mobility decisions, the factors that influence decisions, the process of adjustment in the destination, and the decision model for settled in the destination based on demographic and socio-economic characteristics of migrants.

\section{Literature Review}

The mobility process describes a series of activities carried out by migrants as mobility actors from the area of origin to the destination area. The series of activities that constitute the mobility process concerns the process of: 1) Decision making for mobility includes: factors that influence the decision to mobility both factors in the origin and destination areas, sources of information about the existence of work in the destination area, and decision makers do mobility and source of decision-making reinforcement; 2) The process of departure to the destination area; and 3) The process of adjusting in the destination area in obtaining employment and residence, including sources of information and sources of assistance in finding work and residence in the destination area.

There are several theories about why a person makes a decision to do mobility, including the theory of need and stress (need and stress). Each individual has needs that need to be met. These needs can be in the form of economic, social, and psychological needs. If these needs cannot be met, the stress occurs. High and low stress experienced by individuals is inversely proportional to the proportion of meeting those needs. There are two consequences of this stress. If someone's stress is not too big (still within tolerance), that person will not move. He still lives in the area of origin and adjusts his needs to the existing environmental conditions. If the stress experienced by someone outside the tolerance limit, that person starts to think about moving to another area where their needs can be met. Or in other words, someone will move from an area that has a lower utility value (place utility) to an area that has a higher utility value, where his needs can be met. Means the difference in utilities between regions, greatly determine where the flow of mobility goes.

According to Mitchell (Mantra, 1999), there are several forces that cause people to be attached to the area of origin, and there are also forces that encourage people to leave the area of origin. The power that binds people to stay in the area of origin is called centripetal forces and the force that drives a person to leave the area of origin is called centrifugal forces. Whether someone will remain in their area of origin or leave the area of origin to settle in another area, depends on the consideration of the two forces. 
The resources owned by an area can be a centripetal force for people to live in the region and at the same time be a centrifugal force for people to leave the area. Economically, these two forces can be used as indicators to see the value of the usefulness of an area which is a macro determinant of population mobility. These indicators can include the income or expenditure per capita of the population, the level of wages, and employment opportunities reflected by the unemployment rate. These factors are the positive attraction of population mobility.

A person's motivation to move is an economic motive, the motive developed because of economic disparities between regions (Lee, 1966; Todaro, 1979; Titus, 1982). Todaro (1979) refers to these main motives as rational economic considerations. Mobility to urban areas has two expectations, namely the expectation of getting a job and the expectation of earning a higher income than that obtained in rural areas. Therefore, the movement of the population also tends to go to cities that have relatively large forces, so that they are expected to be able to fulfill their economic benefits.

De Jong \& Gardner (1981) in his theory called the value expectancy theory, explains that the decision to migrate and determine the choice of destination to migrate is the result of the accumulation of various values of the reality they will experience. In determining the choice of destination, it is important that prospective migrants are familiar with the destination area, so that evaluation can be carried out. Decision making is a series of emphasis on the relationship of attitudes, values, perceptions, and intentions to migrate.

Mabogunje (1970) sees the contribution of previous migrants in urban areas as very large in assisting new migrants coming from rural areas or the same area as them, especially in the initial stages of the adjustment mechanism in the destination area. According to Hugo (1986), an interesting thing in various big cities in Indonesia is the gathering of migrants who come from certain regions in the same group of work. This concentration shows the importance of the meaning of migrant chain.

Jellinek (1986) reveals that migrants arrive in the city through a chain migration process, they are assisted by a private network of friends and relationships in the city that provide jobs, food and accommodation. Most already have relatives or acquaintances in the destination area who function as temporary shelters before getting a permanent place. This pattern is a strategy of adjustment to get a job in the city, so in general they have the same type of work as their previous relatives. Furthermore Jellinek revealed that the migrants did not fully live the life of the city because of the factors related to the area of origin which are the result of rational thinking given their goal to the city is to find work.

Research on mobility actors in Surabaya has been carried out by Steele (in Manning \& Effendi, 1996) who revealed the role of the network system in informal sector work in cities. Potential mobility actors who will enter informal activities in the city are potential mobility performers who were previously given promises for certain jobs by relatives who have the same socioeconomic background when they have not entered informal activities in the city. The work offered tends to be similar to the work done before. The social economic background of the mobility players is quite influential in the process of obtaining employment in the city. In this study, it was found that there was a relationship between the 
level of education of mobility actors who originally worked in the agricultural sector with their ease in entering employment opportunities in cities that needed or somewhat needed skills. In fact it was found that their low level of education in the area of origin would affect the low status of work entered in the city. The research shows that the level of education and socioeconomic status prior to mobility, affects the opportunity to enter work in the city and will ultimately affect the level of income in the city.

$\mathrm{Lu}$ (2008) discusses whether health conditions are related to migration decisions in the context of migration population growth in Indonesia. This research found support for the allegation, in addition to demographic and socio-economic factors, health considerations also play a role in migration decision making. But the relationship between health and migration is complicated because migrants are a heterogeneous group: younger migrants are positively chosen with regard to health while older migrants are negatively chosen. The results of Lu's research (2008) show that migrants in Indonesia tend to be chosen in connection with health and that this selection is strong for household heterogeneity that is not observed. However, the strength and direction of health-migration associations vary according to migration type and health dimensions.

Gray \& Mueller (2012) research on drought and population mobility in rural Ethiopia, using the historical event method and unique longitudinal dataset from the rural highlands of Ethiopia to investigate the effects of drought on population mobility over a 10 -year period. The results show that male labor migration increases with drought and that land-poor households are the most vulnerable. However, the steps to marry by women are also reduced by drought.

Furthermore, studies on spatial mobility in life contexts have been carried out by Clark \& Withers (2007), finding that almost a quarter of all respondents who make a move, report something other than work or housing adjustments as the most important factor in their mobility behavior. This finding, especially that at least a large proportion of short distance movements have an employment explanation. Clark \& Huang (2004) further examine the relationship between migration and mobility: individual and contextual effects on the housing market in the United Kingdom, found that migration and mobility are truly embedded in complex life decisions.

Ogena \& De Jong (1999) explore the effects of temporary and more permanent internal migration, together with family resources and individual human resource attributes, on the upward and downward employment transition of workers in Thailand. Four multinomial logit models and job transition goals were estimated using the 1992 National Migration Survey in Thailand. The results show that the more frequent phenomenon of temporary migration is consistently associated with lower employment transition rates and decreased job mobility. More permanent migration is associated with upward and downward mobility of work, and migration to Bangkok only affects the transition of certain employment sectors.

\section{Method}

The study was conducted in several locations that have a large number of migrants, in 
addition to considering the work of most of the population in the study site. Denpasar is divided into four districts namely, West Denpasar District, North Denpasar, East Denpasar and South Denpasar. According to the Denpasar City Population and Civil Registry Office, the highest number of KIPS (Temporary Resident Identity Card) holders per District in Denpasar City in 2013, was found in South Denpasar Subdistrict, which was 12,658 inhabitants, while West Denpasar Subdistrict was second with the population having KIPS as many as 8,410 people.

In addition to the above considerations, the employment of most residents of the West Denpasar District is the tertiary sector which includes trade/hotels and restaurants, transportation, finance and services. Likewise for the District of South Denpasar, the majority of the employment of residents is in the services, trade, and industry. Based on the considerations above, in this study the South Denpasar District and West Denpasar District were selected as the research sample. The locations for taking respondents were not carried out in all village in the two sub-districts, but were determined purposively.

Respondents in this study are individuals who have criteria as workers from outside Bali who work in the informal sector, are perpetrators of mobility/migrants both permanent and non-permanent, and are in the study location, namely Denpasar Barat District and Denpasar Selatan District.

Sampling in this study was conducted by purposive sampling, which is a sampling technique in which sample selection is carried out with certain subjective considerations based on several characteristics of the sample, which are seen to be closely related to population characteristics that have been known previously. Considerations used in selecting respondents are working as informal sector workers (street vendors, hawkers, masseurs, souvenir vendors, personal services, and other types of informal work), as well as migrants from outside Bali, both permanent and non-permanent migrants. The number of samples in this study were set as many as 150 respondents.

Data collection in this study was conducted by interviewing questionnaires, in-depth interviews, and observations in the field. The questionnaire is used to collect data by structured interviews with respondents, containing a list of questions in accordance with the desired data. Data collected includes demographic and socio-economic characteristics, and mobility processes.

The variables used in this study are demographic and socioeconomic characteristics variables including the following variables: Age, Gender, Marital status, Education level, Respondent status in the household, Number of household members, Length of stay in Denpasar City, Status of residence / home ownership, current main occupation, Reasons for choosing the main occupation currently occupied, Length of occupying work / business, Hours of work per day, Number of working days per week, side jobs, income, and expenses. The mobility process variables include: Region of origin of migrants, Occupation in the area of origin, Have lived in another place before their current place of residence, Place of residence before their current place of residence, Reasons for having lived in another place before in this place, When moved to this village, Reasons for choosing Last place of residence, Reasons for 
mobility to Denpasar City, Reasons for choosing to work in Denpasar City, Sources of information about the destination area, Sources of mobility decisions, Sources of reinforcement that have the role of encouraging /supporting in mobility to this city, Sources of assistance for first-time travel costs, Waiting time to get a job for the first time, a source of help getting a job for the first time, a source of underwriter of daily living expenses, a source of help getting a place to stay for the first time. The dependent variable is the decision to settle in the destination area (Yes, there are plans and no plans).

The qualitative data collection was carried out by in-depth interviews with 10 informants, consisting of 2 key informants, 2 expert informants, and 6 incidental informants. In implementing this method, guidelines for in-depth interviews and a list of informants are prepared. The informants interviewed consisted of key informants namely village heads in the two sub-districts studied, expert informants namely practitioners from the civil registry service, incidental informants (man on the street) ie anyone who could provide information such as long-lived migrants, new migrants - recently stayed at the study site, and other informants who can provide information that supports the research objectives.

To complete the results obtained from interviews with questionnaires and the results of in-depth interviews, data will be collected by observation. Observations will be made to see and observe directly the conditions of residence, economic activities including the type of work, merchandise sold (for respondents who have a type of work as seller), and other things that support the research objectives.

Data analysis techniques in this study, followed the following steps: (1) Conducting descriptive analysis to get a description of the demographic and socio-economic characteristics of informal sector migrant workers and mobility processes, by determining the percentage of variables univariately and (2) Conducting multivariate analysis techniques using logistic regression analysis.

Regression is a statistical method that utilizes the relationship between two or more quantitative variables so that one variable can be predicted from other variables (Neter, 1997). Logistic regression analysis according to Hosmer \& Lemeshow (2000) is a regression method with the response variable $\mathrm{Y}$ being categorical or dichotomous, while the independent variables are categorical and / or continuous variables.

All data was edited, collected, and analyzed using the help of SPSS 19.0 and MINITAB 17. The logistic regression analysis was carried out to find a model between demographic and socioeconomic variable variables with variable Y1 = Plans to settle in the destination areas grouped into 1) Yes, there is a plan and 2) There are no plans

\section{Results and Discussion}

\subsection{Description of Respondent Characteristics}

General description of the socioeconomic characteristics of informal sector migrant workers from outside Bali in Denpasar City based on the results of data analysis obtained the average age of informal sector migrant workers who were respondents in this study was 40.49 years, gender dominated by men, namely 64,0\% (96 respondents) out of a total of 150 respondents. 
The pattern seen that migrant workers in the informal sector is dominated by those who are married, namely $84.0 \%$ (126 respondents), while with an unmarried status of $11.3 \%$, only a small proportion with divorce status (4.7\%). These characteristics of age, sex and marital status are consistent with the characteristics of informal sector actors in general. Manning \& Effendi (1996) explain that the informal sector is mostly carried out by the population at the middle age or prime age (30-49 years) in the workforce. Based on the level of education, the majority of respondents in this study had a high school education level (40.7\%), then followed by elementary school level education (28.0\%), junior high school (20.7\%), tertiary education $(8.7 \%)$, and not attending school is only $2.0 \%$.

Resident's house ownership status mostly occupies houses with individual contract status (36.7\%), joint contracts $26.7 \%$, houses with self-owned status are stated by $22.7 \%$ of respondents, and others $14.0 \%$. In general it can be said that the majority of respondents occupy houses with contracting status both individually and jointly contracting that is $63.4 \%$. Respondent status in the household was obtained mostly as head of household (57.3\%), Wife $(30.7 \%)$, status as children and others $12.0 \%$. The average number of migrant household members is 4 person. Most respondents had 3-4 household members (64.6\%), followed by respondents with 5-7 household members (29.4\%), and only $6.0 \%$ of respondents with 1-2 household members.

Table 1. Demographic and socio-economic characteristics of respondents

\begin{tabular}{llrr}
\hline Variable & Category & Frequency & Percent \\
\hline 1. Sex & 1. Female & 54 & 36.0 \\
& 2. Male & 96 & 64.0 \\
\hline 2. Marital status & 1. Unmerried & 17 & 11.3 \\
& 2. Merried & 126 & 84.0 \\
& 3. Divorced & 7 & 4.7 \\
\hline 3. Level of education & 1. Not attending school & 3 & 2.0 \\
& 2. Elementary School & 42 & 28.0 \\
& 3. Middle School & 31 & 20.7 \\
& 4. High School & 61 & 40.7 \\
& 5. Higher Education & 13 & 8.7 \\
\hline \multirow{3}{*}{ 4. Status in the Household } & 1. Head of household & 86 & 57.3 \\
& 2. Wife & 46 & 30.7 \\
& 3. Child & 16 & 10.7 \\
& 4. Others & 2 & 1.3 \\
\hline \multirow{3}{*}{ 5. Status of Residence / } & 1. Self-owned & 34 & 22.7 \\
Home Ownership & 2. Joint contract & 40 & 26.7 \\
& 3. Individual contract & 55 & 36.7 \\
& 4. Others & 21 & 14.0 \\
\hline \multirow{3}{*}{ 6. Main Job Types } & 1. Trader/seller & 85 & 56.7 \\
& 2. Labor & 18 & 12.0 \\
\hline \multirow{2}{*}{ 7. Had additional job } & 3. Entrepreneurship & 40 & 26.7 \\
& 4. Personal Services & 7 & 4.7 \\
\hline
\end{tabular}

Sources: Primary data 
The status of respondents' migration which is seen from the length of stay, the average length of stay as a migrant in Denpasar City is 14.11 years. Most of the migrant workers who were respondents in this study worked as traders $(56.7 \%)$, followed by types of entrepreneurial work $(26.7 \%)$ and a small portion as labor and individual services $(16.6 \% \mathrm{t})$, with the duration of running business average of 8.08 years.

Based on the results of the respondents' data collection, the average hours worked per day is 9 hours/day, with an average number of working days 6 days a week. The distribution of respondents with work hours $\leq 8$ hours/day was $54.7 \%$, while the rest worked with work hours $\geq 9$ hours $(45.3 \%)$. Income derived from work in the informal sector is obtained on average monthly income of IDR.4,270,000 with a very wide range between minimum income (IDR.1,000,000) and maximum income (IDR.15,000,000). The average expenditure of respondents is IDR.2,851,333 per month. Regarding the presence/absence of additional jobs from respondents other than the main occupation currently occupied, obtained most respondents $71.3 \%$ did not have additional jobs.

\subsection{The Mobility Process of Informal Sector Migrant Workers}

The area of origin of the respondents is dominated by migrants with regions from East Java Province, namely Jember, Banyuwangi, and Surabaya. Distribution of respondents according to region of origin, most migrants were from Java (88.7\%), while the rest came from various regions in Indonesia (11.3\%). Many factors cause the flow of population movement, one aspect that can be seen is their original work in the area of origin. By knowing the background of this type of work, it is expected to know whether their movement is really to get a better job to increase income.

Respondents' work in the area of origin in the last job before moving to the city of Denpasar, the survey results show that the work of respondents in the area of origin varies. The dominant percentage is Not Working $(40.7 \%)$, then followed by the type of work as employees $(12.7 \%)$, traders $(12.0 \%)$, Labor $(12.0 \%)$, farmers $(11.3 \%)$, personal services $(6.7 \%)$, the rest are entrepreneurs and gardening.

As many as $40.7 \%$ of respondents stated that they did not work in their original area, and $59.3 \%$ of respondents said they had worked in their home area. The percentage of migrant workers who previously stated that they do not work indicates a high number. This is very possible especially for migrant workers who are classified as young. The respondents stated that the reason for not working in their home areas was because they still received education and because they really did not work in their home regions. With the invitation of friends and relatives, or because of their own volition to improve the economic situation and to gain new experience in the destination area, they are determined to make an effort to go abroad.

Migrant workers who work as farmers in their home areas, mobility to the city of Denpasar more due to natural resource factors in the area of origin. Some respondents revealed that the condition of the agricultural land they worked on was a minus area that did not promise a change in their household economy. The condition of the barren land and the narrow agricultural land that they have caused them to decide to mobility. Another respondent's answer was that the activity of agriculture was seasonal, so that in certain seasons they could find other work alternatives to supplement their household income.

\subsubsection{History of the Mobility of Migrant Workers before Arriving in Denpasar City}

Migrant workers who have decided to mobility to Denpasar, where they lived before 
Denpasar (the last place to live) are in another province, another district, another sub-district, or another village in one sub-district in Southern Denpasar or Western Denpasar.

Overall from all respondent of this study, $52.7 \%$ (79 respondents) stated that the have live in other different places other than this place (the last place which study was conducted) and 47.3\% (71 respondents answered that they never had never lived anywhere else before. Mobility actors who claimed to have lived in another place after leaving their area of origin, carried out several stages of the previous transfer, and then finally at the last stage (when the study was conducted) they lived in the city of Denpasar. Whereas the mobility actors who claim they have never lived elsewhere, are migrants of one stage, who directly transferred from the area of origin directly to their destination, namely where they are living now (when the research was conducted).

Most of the of respondents $(41.8 \%)$ who said they had lived previously in another place, the previous residence was in another village but still in one sub-district with their current residence, $36.7 \%$ of respondents said they had lived in another sub-district before but still in the sub-district inside the area of Denpasar City, as many as $12.7 \%$ stated they had lived previously in other districts in Bali Province, and the rest (8.8\%) said they had lived before in other provinces.

The mobility actors who claimed to have lived elsewhere before $(52.7 \%)$ undertook several stages of transfer before deciding to stay in Denpasar. The occurrence of this tendency is explained by Harre (1966), that migrants in determining the area to be a permanent residence for the whole family is not easy, but through various stages and processes requires a long time, the decision to settle in one area considerably takes a long time. While the migration process can continue and has been undertaken by migrants as needed.

The results of in-depth interviews with several informants in the study area obtained an information that most of them revealed that the first place of residence when they first arrived in Denpasar City was different from their current place of residence. In fact, many have moved more than twice. This is in accordance with the development of business they run and the economic progress they have gained while in the destination area.

According to Gilbert \& Gugler (1996) the mobility of individuals is the focus of much migration analysis, and this trend is supported by the fact that migration usually involves young people who are still not married. But in many cases migration is not only a mobility at once, it seems that there are types of migration that gradually over time or are called migration careers. As the decision to migrate is rarely considered separately, so migration can also be understood when referring to family and community.

Mobility actors residing before their last residence in Denpasar, have certain reasons, including reasons for work, joining spouse, joining parents, and other reasons. Most respondents who stated that they had lived previously in another place were dominated by work reasons, namely as many as $43.6 \%, 29.5 \%$ due to reasons for joining spouses, $11.5 \%$ due to joining parents, and $15.4 \%$ for other reasons.

Mobility actors who carry out several stages of transfer due to work reasons, this can be explained because the mobility actors will look for places that can provide hope for work, so they will carry out several stages of migration to areas that can provide better employment opportunities. As long as there are opportunities/job opportunities that are better than their previous job, then they will continue to move to a place which promises better expectations. Regarding this phenomenon, Lee (1966) stated that the intervening opportunity, that in order 
to work, an intervening opportunity is an opportunity to get a better destination. In this area through an intervening opportunity, a migrant prepares the actual destination.

The reason respondents chose their current place of residence, $42.0 \%$ because of reasons close to the place of work/place of business, as many as $26.0 \%$ lived in the current place of residence because of reasons to join their husbands or parents, $16.7 \%$ because of lower prices/rental fees compared to other places, $9.3 \%$ because of the reason that the respondent bought a house in this sub-district (at the time of the study), and only $6.0 \%$ with the reason close with relatives.

Respondents' answers regarding the underlying reasons for choosing a place to live are dominated by considerations near the place of work/business. The results of in-depth interviews with several informants also reinforce this. Some informants revealed that in looking for a place to live, not solely for residential but also for a place of business. Another consideration is the strategic location of the business and the consideration of the smooth running of the business. Many of them directly conduct business activities in the neighborhood of villages and settlements in the study area. They use the denseness of the population in the settlement as an asset for good marketing areas, among them are mobile vendors who sell goods such as clothing, food (meatballs, satay, and raw food ingredients).

Furthermore, there is a pretty big percentage (16.7\%) of respondents' answers in choosing a place to stay for other reasons. They stated that the change of residence was due to expensive housing costs, so that many of them moved from one neighborhood to another, looking for low-rent housing.

\subsubsection{Mobility Decision Making Process}

The decision-making process for mobility in a person is influenced by the existence of information about the destination areas which came from various parties, also influenced by who the decision maker is and the source of decision support. Factors that influence decisions both from the area of origin and pull factors in the destination also contribute to the decision.

The role of relatives/family $(50.0 \%)$ as well as regional friends $(29.3 \%)$ in this study is very large in conveying information to relatives/families who are still in the area of origin. Information which delivered directly is usually more quickly and able to influence them to decide whether or not to mobility. Especially if coupled with the tangible results they bring from the city. This will further convince them that the area they are going to provides a lot of hope for their survival will be better. This is in accordance with the opinion expressed by De Jong \& Gardner (1981) regarding considerations in mobility decision making, that the role of previous migrants as carriers of information is very large which is a consideration for potential mobility actors.

Sources of information from relatives/family who are blood relatives will ensure the certainty of employment in the destination area. Whereas the main source of information from these local friends proves that in a certain area there are sometimes workers that are dominated by workers who come from a certain area.

Sources of information about the destination area play an important role for prospective migrant workers when they decide to make mobility. For workers the role of information about employment in the destination area is quite large. Besides that, an information will influence the perception about destination area which in turn determines further decisions

Mobility decision makers are decided solely by mobility actors, or it can also be decided by 
other parties such as husband / wife, parents, and other parties. The percentage distribution of mobility decision makers based on respondents' answers was obtained that the majority stated that mobility decisions were decided by themself or husband $(61.3 \%)$, by relatives/family (34.0\%), by regional friends and returning migrants $(4.7 \%)$.

The dominance role from sibling/family and husband/wife in mobility decision making is revealed by Mabogunje (1970) in the General Systems Theory which states that the village control sub-system influences the flow of the system. It was revealed that in rural areas what is meant by the village control sub-system are families who have influence in making decisions for mobility, such as in terms of migrant marital status, age, economic dependency, inheritance system that encourages children who get little inheritance to migrate, agricultural land and agricultural production ownership are the deciding factors for consideration in migrating

Hugo (1995) explains that decisions for mobility are highly determined and influenced by families. Someone in making a decision to do mobility is not a decision taken suddenly, influenced or based on careful consideration of the obstacles that may arise and the benefits that may be obtained. The decision was not only made on its own but also based on considerations from various parties. For those who are married, apart from themselves, the husband/wife takes the decision to do mobility or not. Whereas the unmarried mobility actors who are considering mobility other than themselves, parents also determine.

The mobility decision is very much influenced by the encouragement of various parties. Respondents 'answers in this study regarding those who played a role in encouraging/ supporting respondents to mobility were dominated by parents' encouragement $(39.3 \%)$, then by spouses $(28.7 \%)$, relatives/family $(16.7 \%)$ and self-encouragement $(15.3 \%)$. The involvement of husband/wife, parents, siblings, especially the oldest, has a great influence on the mobility decision. Another factor that needs to be revealed is the issue of family needs is crucial to determine whether or not to make mobility decisions. The mobility actors go to make ends meet such as seeking capital to finance their children's schools. Besides that, the existence of kinship networks in the destination areas is also decisive.

\subsubsection{Factors Affecting Mobility Decisions}

The problem of population movement from one area to another, especially from villages to cities, often raises the reason that cities have far more strong appeal than rural areas. This is one of the reasons why they make the decision to do mobility. Another reason is that the city is seen as providing a great opportunity to get a decent job.

Respondents' answers regarding the most underlying reasons for the decision to move to Denpasar were dominated by reasons for getting a job (74.7\%), while for reasons of urban progress (complete city facilities, education, entertainment, health, and other facilities) were answered by $14.7 \%$ of respondents, while other reasons (higher wages, seeking experience outside the region, wanting to leave, joining relatives, etc.) were answered by $10.7 \%$ of respondents.

The most dominant reason underlying the mobility decisions in this study was because there was an urge to get a job in the destination, which was answered by 112 respondents $(74.7 \%)$, when tracing the reasons why they chose to work in Denpasar city, most of the respondents stated that because of their salary/wages higher than in the area of origin (39.3\%), because it is easier to find work than in the area of origin (38.4\%), the survival of households in the area of origin $(17.9 \%)$, and other reasons $(4.5 \%)$. The reasons which are the driving factors are in 
accordance with what was stated by Lee (1966), that the driving factors at the place of origin are generally considered negative by migrants, so they feel the need to leave the place of origin, including being mentioned because of lack of employment opportunities and because income is not sufficient.

The survey results in this study are in accordance with what was stated by Lee (1966) that the pull factor that exists at the destination has a high welfare value and is considered positive by migrants, so the mobility actors decides to migrate. This is due to the wide-open employment opportunities in the destination area, so the opportunity to carry out economic activities is greater. In line with what was revealed by Mabogunje (1970) that potential migrants in migrating are encouraged and influenced by environmental factors, and one of these environmental factors is the factor of economic conditions and wages.

\subsubsection{Process of Departure to Destination Areas}

The decision to mobility has certain consequences. The intended consequences include sources of assistance with the cost of the first trip to the destination. Sources of travel costs to destinations can be from own money, parents, local friends, and can also be in the form of loans.

The results of this study indicate that as many as $61.3 \%$ of respondents made their first trip to their destination at a cost that originated from their own money, 35.3\% came from relatives/family, and the rest from other sources. The dominance of first-time travel financing sources from one's own money shows that the cost of travel is not a problem for the distance between Java and Denpasar, because it requires relatively low costs, which shows that migrant workers independently finance their first trip to Denpasar.

Besides that, there is also a large role of relatives/family in funding migrant travel for the first time, which shows that the transfer of family members is the hope of all family members who will accompany, with this expectation, parents or relatives/family also provide material support for migrant departures to the destination area.

\subsubsection{The Adjustment Process in the Destination Area}

Mobility actors after arriving at the destination do not immediately get a job, but wait first. The results showed that the average length of waiting for a first-time job was 30 days $(29,987$ days). Migrants with 1 week waiting period (46.7\%), 10 days-3 weeks (18.0\%), >3 weeks - 1 month $(15.3 \%)$, and $>1$ month $(20.0 \%)$. Overall research respondents mostly waited for work about 3 weeks $(64.7 \%)$. This can be explained because these mobility workers work in informal sector types of work so that it does not require a relatively long time to get the job. In general, they can directly carry out activities by getting a few hints from their previous colleagues, aside from the fact that the types of work in the informal sector, which are mostly occupied by mobility actors, do not require diverse requirements.

The length of waiting time to get a job for the first time is relatively short ( $\leq 3$ weeks), this can be explained given the condition of Denpasar City which has great opportunities in providing employment opportunities, especially to fill vacancies in the type of manual work or types of work in the informal sector.

Mobility actors receive help in getting a job and first place to live from various parties. The source of assistance in getting a job for the first time in this study was a source of assistance from family/relatives (34.7\%), themselves (42.7\%), regional friends (19.3\%) and other sources (3.3\%). Assistance in finding a job in the destination area first affects the length of 
waiting for first time employment. Those who did not get assistance (themselves) in obtaining employment for the first time were indicated to have an average length of waiting to get a longer job compared to migrants who received assistance from various sources. So far there has not been an analysis of this matter.

Sources of assistance in getting a place to live for the first time, the results of this study indicate the dominance of finding one's own place to live (52.0\%), accommodated by relatives/family $(36.0 \%)$, accommodated by friends of origin $(10.7 \%)$, and others $(1.3 \%)$. Respondents with a place of residence were first accommodated by local friends and relatives/family or other relatives, even though the first time they lived in a very crowded location, this was because they did not yet understand their new environment. The process of their adjustment will be smoother if it has received instructions from previous migrants. Likewise, only with the source of assistance in meeting the cost of living the first time before getting a job. Most of the respondents stated that they alone paid for their living expenses $(62.7 \%)$, by relatives/family $(34.7 \%)$ and the rest were from local friends and others.

The substantial role of relatives/family in getting a job, a place to live, and supporting the cost of living for a migrant for the first time, shows that the assistance of relatives/family (having blood and marriage ties) will be more secure to find work and accommodate in the destination. Keesing in Kartini (1995) revealed that the kinship ties of the migrants found in urban areas were still the basis for social unity and shared action characteristics where the kinship ties were not only limited to blood relations or marriage, but were more directed to the same interests. Furthermore, it is said that family relations in Javanese society can be seen as a network that is held on the basis of the common ancestry and on social ties.

The conclusion which states that kinship is not only based on blood ties or marriage is a reality that must be accepted. Especially if it was observed in rural community life, existing family ties are more flexible ties. Not only based on blood relations but a relationship can caused by the existence of a common interest. If it is related to the process of mobility actors' self-adjustment in the city, then the bond of kinship will be felt as a relationship that is based more on equality of fate and interests. This kinship bond has a lot to do with the state of mobility actors who have just arrived in the city.

\subsection{The Model of the Decision to Settle in the Destination}

Logistic regression analysis was carried out to find a model between the variables of demographic and socioeconomic characteristics with the variable Y1 = Plans to settle in the destination areas grouped into 1) Yes, there are plans and 2) No plans.

Logistic regression model with response variable Sedentary Decisions with significant independent variables in the model include age, number of hours worked per day, amount of income from main work, monthly expenses, home ownership status, first place of residence in Denpasar, and sub-district areas in Denpasar city (0. South Denpasar, 1. West Denpasar).

The logistic probability estimation function is expressed as

$$
\widehat{\pi_{1}}=\frac{\exp \left(b_{0}+\sum_{j=1}^{k} b_{j} X_{j i}\right)}{1+\exp \left(b_{0}+\sum_{j=1}^{k} b_{j} X_{j i}\right)}
$$

and the logistic regression estimation function is stated as: 


$$
\ln \left(\frac{\widetilde{\pi}_{i}}{1-\widetilde{\pi}_{i}}\right)=b_{0}+\sum_{j=1}^{k} b_{j} X_{j i}
$$

Hosmer \& Lemeshow Test is a Goodness of fit test (GoF), which is a test to determine whether the model formed is correct or not. Said to be appropriate if there is no significant difference between the model and its observational value.

Ho: The model that was formed is right

$\mathrm{H}_{1}$ : The model formed is not appropriate

Table 2. Omnibus Tests of Model Coefficients

\begin{tabular}{|c|c|c|c|c|}
\hline & & Chi-square & $\mathrm{df}$ & Sig. \\
\hline \multirow[t]{3}{*}{ Step 1} & Step & 70.341 & 11 & .000 \\
\hline & Block & 70.341 & 11 & .000 \\
\hline & Model & 70.341 & 11 & .000 \\
\hline
\end{tabular}

Table 3. Model Summary

\begin{tabular}{lrrr}
\hline Step & -2 Log likelihood & Cox \& Snell R Square & Nagelkerke R Square \\
\hline 1 & $136.936^{\mathrm{a}}$ & .374 & .500 \\
\hline
\end{tabular}

a. Estimation terminated at iteration number 6 because parameter estimates changed by less than .001.

Table 4. Hosmer and Lemeshow Test

\begin{tabular}{llllll}
\hline Step & Chi-square & df & & Sig. \\
\hline 1 & 3.371 & & 8 & .909 \\
\hline
\end{tabular}

The results of this test indicate Ho is accepted, meaning that the model formed is correct (there is no significant difference between the model / estimated value and the observed value).The accuracy of the model in classifying responses is stated in Table 5.

Tabel 5. Classification Table ${ }^{\mathrm{a}}$

\begin{tabular}{|c|c|c|c|c|c|}
\hline & & & & Predicted & \\
\hline & Ohcerved & & Plan for_ & ettle & \\
\hline & Uoserved & & $\begin{array}{l}\text { Yes, there are } \\
\text { plan }\end{array}$ & No plan & $\begin{array}{c}\text { Percentage } \\
\text { Correct }\end{array}$ \\
\hline Step 1 & Plan for_settle & $\begin{array}{l}\text { Yes, there are } \\
\text { plan }\end{array}$ & 61 & 19 & 76.3 \\
\hline & & No plan & 13 & 57 & 81.4 \\
\hline & Overall Percent & & & & 78.7 \\
\hline
\end{tabular}

a. The cut value is .500

Table 5 shows that the accuracy of the model in classifying responses was $78.7 \%$. The estimated parameters of the logistic regression model are shown in Table 6. Table 6 gives an estimation of the logistic regression model for this study's data, then it is stated in equation 3. 
$Y_{i}=$

$3.618-0.048$ Age -0.141 Hours_work_per_day $-3,925$ Home_ownership(1) $i$ -

0.349 Home_ownership(2)i - 2.021Home_ownership(3) $i+$

2.222Residence1(1) $i+2.077$ Residence1(2) $i+0.543$ Residence1(3) $i-$

0.958 District(1)i

(3)

With $\mathrm{i}=0$ if no plan for settle and $\mathrm{i}=1$ if there is a plan for settle.

Tabel 6. Variables in the Equation

95\% C.I.for

$\operatorname{EXP}(\mathrm{B})$

\begin{tabular}{|c|c|c|c|c|c|c|c|c|c|}
\hline & & B & S.E. & Wald & df & Sig. & $\operatorname{Exp}(B)$ & Lower & Upper \\
\hline Step & Age & -.048 & .024 & 4.025 & 1 & .045 & .953 & .909 & .999 \\
\hline \multirow[t]{13}{*}{$1^{\mathrm{a}}$} & Hours_work_per_day & -.141 & .082 & 2.983 & 1 & .084 & .868 & .739 & 1.019 \\
\hline & Main job_income & .000 & .000 & 8.914 & 1 & .003 & 1.000 & 1.000 & 1.000 \\
\hline & Expenses_per_month & .000 & .000 & 9.417 & 1 & .002 & 1.000 & 1.000 & 1.000 \\
\hline & Home_ownership & & & 22.407 & 3 & .000 & & & \\
\hline & Home_ownership(1) & -3.925 & .988 & 15.789 & 1 & .000 & .020 & .003 & .137 \\
\hline & Home_ownership(2) & -.349 & .658 & .281 & 1 & .596 & .705 & .194 & 2.562 \\
\hline & Home_ownership(3) & -2.021 & .667 & 9.192 & 1 & .002 & .132 & .036 & .489 \\
\hline & Residence 1 & & & 10.922 & 3 & .012 & & & \\
\hline & Residence1(1) & 2.224 & 1.692 & 1.727 & 1 & .189 & 9.245 & .335 & 254.999 \\
\hline & Residence1(2) & 2.077 & 1.791 & 1.345 & 1 & .246 & 7.981 & .239 & 266.903 \\
\hline & Residence1(3) & .543 & 1.672 & .106 & 1 & .745 & 1.722 & .065 & 45.604 \\
\hline & District(1) & -.958 & .462 & 4.307 & 1 & .038 & .384 & .155 & .948 \\
\hline & Constant & 3.618 & 2.125 & 2.897 & 1 & .089 & 37.251 & & \\
\hline
\end{tabular}

a. Variable(s) entered on step 1: Age, Hours_work_per day, Main job_income, Expenses_per_month, Home_ownership, Residence1, District.

The interpretation of the model in equation 3, shows that the factors that significantly influence migrants' decision to settle in the destination area of Denpasar City are the variables of age, hours of work per day, status of home ownership, source of assistance for the first time residence, and sub-district of respondents.

Age with a binary logistic regression coefficient $(B)$ of -0.048 or $\operatorname{Exp}(B)=0.953$ shows an increase in 1 year of age of respondents decreases the chance to decide not to settle in Denpasar to $95.3 \%$ (the amount of decline $(100-95.3) \%=4.7 \%$ ). It can also be interpreted that an increase in 1 year of age of respondents increases the chance of making a decision to settle in Denpasar City is $4.7 \%$

The number of working hours per day with a coefficient B of -0.141 or the value of Exp $(B)=$ 0.868 shows an increase in respondent's working hours per day 1 hour decreases the chance 
of deciding not to settle in the city of Denpasar to $86.8 \%$ (the decrease is $(100-86.8) \%=$ $13.2 \%$ ). Or an increase of 1 respondent's working hours per day increases the chance of setting a decision to settle in Denpasar by $13.2 \%$.

Based on Table 6, income from main work and total expenditure per month has a very small coefficient value, almost 0 so that the value of $\operatorname{Exp}(B)=1$, this shows that the two variables have a significant effect, but the magnitude of the effect cannot be calculated explicitly. Based on these results, the income and expenditure variables are not included in the model in equation 3.

House Ownership with Home_ownership(1) = House Owned, Home_ownership(2)=

Joint Contract, Home_ownership(3) = Individual Contracts with other forms of ownership can be interpreted that: Opportunity of respondents with their own home plans not to settle in Denpasar city 0.020 or (1/5) of respondents with other home ownership, or can also be interpreted as respondents who have their own home) the opportunity to plan to settle in Denpasar 5 times compared to respondents with other home ownership; Opportunities for respondents with a shared contract house plan not to settle in the city of Denpasar 0.705 or (7/10) of respondents with other home ownership, or can also be interpreted as respondents with a Joint Contract house status have the opportunity to plan to settle in Denpasar 10/7 times compared to respondents with other home ownership; Opportunities for respondents with individual contract house status plan not to settle in Denpasar City 0.122 or (122/1000) of respondents with other home ownership, or can also be interpreted as respondents with individual contract houses having the opportunity to plan to settle in Denpasar 1000/122 times compared respondents with other home ownership.

Residence1 with Residence1(1): Search by their self, Residence1(2): Hosted by friends from area of origin, Residence1(3): Hosted by relatives/family, on the basis of: Place of residence1 other, it can be stated that: Opportunity of respondents with a place to live the first time looking for their own plans not to settle in Denpasar City amounting to 9,245 times of respondents with other first place of residence; Opportunity for respondents with their first place of residence accommodated by local friends as long as they plan to not settle in Denpasar by 7,981 times that of respondents with other first places of residence; Opportunities for respondents with their first place of residence accommodated by relatives/family planning not to settle in Denpasar City amounted to 1,722 times that of respondents with other first places of residence.

Respondents who reside in Western Denpasar have the opportunity to plan not to settle in Denpasar City by 0.038 times the chances of respondents residing in Southern Denpasar, or can also be interpreted as respondents who reside in Western Denpasar have the opportunity to plan to settle in Denpasar City 1000/38 times compared to respondents who live in Southern Denpasar.

\section{Conclusion and Recommendations}


A history of the mobility of migrant workers before arriving in the city of Denpasar, as much as $52.7 \%$ said they had lived elsewhere before this place (last place, when the study was conducted). Most respondents stated that they had lived previously in another place, where the previous residence was in another village one district (41.8\%) and another district in Denpasar City (36.7\%). Reasons for living elsewhere before, as many as $43.6 \%$ stated because of work reasons, $29.5 \%$ because they joined husband/wife, $11.5 \%$ reasons because they joined their parents, and $15.4 \%$ for other reasons.

Reasons for choosing recent place to live now, because of close to the place of work/place of business $(42.0 \%)$, reasons for joining a husband or parent $(26.0 \%)$, the reason for the cost of renting a house that is cheaper than other places (16.7\%), and the reason that the respondent bought a house in this sub-district $(9.3 \%)$.

The role of relatives/family $(50.0 \%)$ as well as regional friends $(29.3 \%)$ in this study was very large in conveying information to relatives/families who were still in the area of origin. Mobility decision makers, the majority stated that mobility decisions were decided by themselves or their husbands $(61.3 \%)$ and by relatives/family (34.0\%).

The most underlying reason for the decision to mobility to Denpasar was dominated by reasons for getting a job (74.7\%), the reason why migrants chose to work in Denpasar City, respondents stated that because of higher salaries/wages than in the area of origin $(39.3 \%)$, because it is easier to find work than in the area of origin (38.4\%), and the survival of households in the area of origin $(17.9 \%)$. The process of leaving to the destination shows that the respondent made the first trip to the destination at a cost originating from his own money $(61.3 \%)$, sourced from relatives/family (35.3\%), and the rest from other sources.

Overall research respondents mostly waited for work $\leq 3$ weeks (64.7\%). Sources of assistance in getting a job for the first time by sources of help from the family/relatives (34.7\%), themselves (42.7\%), friends from local area (19.3\%) and other sources $(3.3 \%)$. The source of assistance in getting a place to live for the first time, by finding their own place of residence $(52.0 \%)$, accommodated by relatives/family (36.0\%), accommodated by friends of origin (10.7\%). Sources of assistance in first time living expenses before getting a job, respondents stated that they alone bear the cost of living (62.7\%), supported by relatives/family (34.7\%) and the rest by friends from other regions and others.

Based on the obtained model, the factors that significantly influence migrants' decision to settle in the destination area, namely Denpasar City are the variables of Age, working hours per day, home ownership status, source of assistance for first-time residence, and respondent's sub-district of residence.

Based on the research results, the following recommendations can be made: it is necessary to control the flow of incoming migrants, especially those that are non-permanent, so that mobility actors who enter the city of Denpasar in particular and Bali in general truly have work skills and work on the types of jobs that truly experience shortages. labor, so as not to create competition in employment opportunities between migrants and local residents of Bali. Controlling migrant population needs special attention, with better administrative records for 
migrant residents, because it is also intended to anticipate crime.

\section{Acknowledgments}

The highest appreciation to Udayana University for funding this research through the Study Program Excellence Research grant, with Contract Number: 1998/UN14.2.8.II/LT/2019, April 10, 2019

\section{References}

Biro Pusat Statistik. (1993). Profil kependudukan Provinsi Bali. Jakarta: Biro Pusat Statistik.

Biro Pusat Statistik. (2000). Karakteristik penduduk Bali hasil sensus penduduk 2000, Seri: L2.2.16.16. Jakarta: Biro Pusat Statistik.

Badan Pusat Statistik Provinsi Bali. (2010). Hasil Sensus Penduduk 2010 untuk Provinsi Bali. Denpasar: Badan Pusat Statistik Provinsi Bali.

Badan Pusat Statistik Provinsi Bali. (2012). Keadaan ketenagakerjaan Provinsi Bali Agustus 2012, Berita Resmi Statistik, 62. Denpasar: Badan Pusat Statistik Provinsi Bali.

Clark, W. A. V., \& Huang, Y. (2004). Linking migration and mobility: individual and contextual effects in housing markets in the UK. Regional Studies, 38, 617-628. https://doi.org/10.1080/003434042000240932

Clark, W. A. V., \& Withers, S. D. (2007). Family migration and mobility sequences in the United States: Spatial mobility in the context of the life course. Demographic Research, 17(20), 591-622. https://doi.org/10.4054/DemRes.2007.17.20

De Jong. G. F., \& Gardner, R. W. (eds). (1981). Migration decision making: multidiciplinary approach to mircolevel studies in developing countries. New York: Pergamon Press.

Gilbert, A., \& Gugler, J. (1996). Urbanisasi dan kemiskinan di dunia ketiga. Yogyakarta: Tiara Wacana

Gray, C., \& Mueller, V. (2012). Drought and population mobility in rural Ethiopia. World Development, 40(1), 134-145. https://doi.org/10.1016/j.worlddev.2011.05.023

Harre, J. (1966). A Model for the analysis of island emigration. New Zealand: University of Otago.

Hosmer, D. W., \& Lemeshow, S. (2000). Applied logistic regression, (2nd eds). New York: John Wiley and Sons Inc. https://doi.org/10.1002/0471722146

Hugo, G. J. (1986). Migrasi sirkuler, In Kuncoro-Jakti, D. Kemiskinan di Indonesia (pp. 57-91). Penyunting. Jakarta: Yayasan Obor Indonesia

Hugo, G. J. (1995). International labour migration and family: some observation from Indonesia. Asian and Pacific Migration Journal, 4(2-3), 273-301. https://doi.org/10.1177/011719689500400206

Jellinek, L. (1986). Sistem pondok dan migrasi sirkuler. In Kuncoro-Jakti, D. Kemiskinan di Indonesia (pp. 92-124). Penyunting. Jakarta: Yayasan Obor Indonesia

Kasto \& Sembiring, H. (1996). Profil kependudukan Indonesia selama PJP I dan awal PJP II. Yogyakarta: Pusat Penelitian Kependudukan, Universitas Gadjah Mada. 


\section{Macrothink}

International Journal of Human Resource Studies

ISSN 2162-3058 2020, Vol. 10, No. 4

Lee, E. S. (1966). A Theory of migration. Demography, 3, 47-57. https://doi.org/10.2307/2060063

Lu, Y. (2008). Test of the 'healthy migrant hypothesis': a longitudinal analysis of health selectivity of internal migration in Indonesia. Social Science \& Medicine, 67, 1331-1339. https://doi.org/10.1016/j.socscimed.2008.06.017

Mabogunje, A. L. (1970). Systems approach to a theory of rural-urban migration. Geographical Analysis, 2(1), 1-18. https://doi.org/10.1111/j.1538-4632.1970.tb00140.x

Manning, C., \& Effendi, T. N. (1996). Urbanisasi, pengangguran, dan sektor informal di kota. Jakarta: Yayasan Obor Indonesia.

Mantra, I. B. (1999). Mobilitas penduduk sirkuler dari desa ke kota di Indonesia. Yogyakarta: PPK UGM.

Neter, J., Wasserman, W., \& Kutner, M. H. (1997). Model Linear Terapan Buku II. Analisis Regresi Ganda. Bogor: Jurusan Statistika FMIPA IPB.

Ogena, N. B., \& De Jong, G. F. (1999). Internal migration and occupational mobility in Thailand. Asian and Pacific Migration Journal, 8(4), 419-446. https://doi.org/10.1177/011719689900800401

Titus, M. J. (1982). Migrasi antar daerah di Indonesia. Yogyakarta: Pusat Penelitian dan Studi Kependudukan Universitas Gadjah Mada (PPSK UGM).

Todaro, M. P. (1979). Economic for a developing world, introduction to a principles, problem, and policies. Hongkong: Longman.

Statistik Kecamatan Denpasar Barat. (2015).

http://denpasarkota.bps.go.id/web2015/website/pdf_publikasi/Statistik-Daerah-KecamatanDe npasar-Barat-2014.pdf

Statistik Kecamatan Denpasar Selatan. (2015).

http://denpasarkota.bps.go.id/web2015/website/pdf_publikasi/Kecamatan-Denpasar-Utara-Da lamAngka-2014.pdf

\section{Copyright Disclaimer}

Copyright for this article is retained by the author(s), with first publication rights granted to the journal.

This is an open-access article distributed under the terms and conditions of the Creative Commons Attribution license (http://creativecommons.org/licenses/by/4.0/). 